\title{
Motivasi Pendonor Crowdfunding: Studi Kasus di Jono Terbakar
}

\author{
Nihan Anindyaputra Lanisy \\ Jurusan Manajemen, Universitas Gadjah Mada Yogyakarta \\ E-mail: nihan.lanisy@gmail.com
}

\begin{abstract}
ABSTRAK
Tulisan ini bertujuan untuk mengetahui motivasi pendonor crowdfunding pada kelompok musik Jono Terbakar. Jono Terbakar telah melakukan lima kali crowdfunding untuk pendanaan produksi album. Menurut Gerber \& Hui (2014), crowdfunding adalah penggalangan daring terhadap sumber daya kepada orang banyak yang kadang melibatkan imbalan. Imbalan membedakan crowdfunding dengan penggalangan donasi. Jono Terbakar telah melakukan crowdfunding melalui platform digital yang ada (kolase.com, kitabisa.com, wujudkan.com) dan juga pernah menggunakan situs web jonoterbakar.com untuk melakukan crowdfunding. Penelitian ini menggunakan metode kualitatif dengan pendekatan studi kasus analisis deskriptif. Pada penelitian ini, motivasi dibagi menjadi dua variabel: intrinsik dan ekstrinsik. Pada penelitian ini, ditemukan bahwa mayoritas narasumber mengikuti crowdfunding dengan motivasi intrinsik yaitu "mendukung gagasan" dan "membantu orang lain".
\end{abstract}

Kata Kunci: crowdfunding, pendanaan seni, motivasi intrinsik, motivasi ekstrinsik

\section{Motivation of Crowdfunding Donors A Case Study on Jono Terbakar ABSTRACT}

This paper is aiming to know the motivation of the donor who participate in Jono Terbakar's crowdfunding. Jono Terbakar has used crowdfunding five times to fund their albums. According to Gerber \& Hui (2014), crowdfunding is a resource gathering to a mass of people that include reward. Reward makes crowdfunding differ with donation. Jono Terbakar have used the digital platform for crowdfunding (kolase.com, kitabisa.com, wujudkan.com) and also have used their own website jonoterbakar.com to do crowdfunding. This study using qualitative method with case study and descriptive analysis approach. In this study, there are two motivation that is being studied: intrinsic and extrinsic. In this study found that majority of the subject participate in the crowdfunding with the intrinsic motivation which is "supporting the idea" and "helping others".

Keywords: crowdfunding, art funding, intrinsic motivation, extrinsic motivation

\section{PENDAHULUAN}

Internet telah mengubah cara kerja musisi. Menurut wikipedia.com, situs jejaring sosial Myspace telah diluncurkan pada tahun 2003 dan kemudian digunakan oleh banyak musisi untuk menampilkan karyanya. Arctic Monkeys, Bring Me the Horizon, dan Pee Wee Gaskins adalah beberapa nama tenar yang 
memanfaatkan internet untuk mempermudah distribusi karyanya. Selain distribusi karya, musisi kini dapat memanfaatkan internet untuk mengumpulkan dana guna memproduksi album melalui sistem crowdfunding.

Menurut Freedman \& Nutting (2014), situs crowdfunding pertama bernama ArtistShare yang berdiri pada tahun 2003 di Amerika Serikat. Proyek pertamanya adalah penggalangan dana untuk produksi album musisi jaz Maria Schneiders yang berhasil mengumpulkan USD130,000. Setelah itu, bermunculan banyak situs serupa yang banyak dimanfaatkan oleh musisi untuk menggalang dana guna memproduksi album musik. Menurut inc.com, kickstarter.com.com adalah situs crowdfunding terbesar di dunia sekarang ini, dilihat dari jumlah proyek dan dana yang telah berhasil dihimpun. Terdapat beberapa situs crowdfunding di Indonesia, seperti kitabisa.com, kolase.com, dll. Menurut kompas.com, terdapat 143 juta orang di Indonesia yang terhubung dengan internet pada tahun 2017. Hal ini membuat Indonesia memiliki peluang yang sangat besar dalam pengembangan crowdfunding, terutama di bidang musik.

Crowdfunding digunakan oleh musisi untuk mendapatkan dana, dan secara umum, kemudian musisi akan memberikan imbalan kepada para donor. Imbalan disesuaikan dengan jumlah dana yang diberikan oleh donor. Beberapa proyek menerapkan imbalan minimum berupa pencantuman nama donor pada credit album ketika sudah selesai.

Jono Terbakar, sebuah kelompok musik dari Yogyakarta, Indonesia; telah menggunakan crowdfunding sebanyak empat kali untuk mengumpulkan modal produksi album studio. Dalam mengumpulkan modal produksi, menurut wujudkan.com, Jono Terbakar menggunakan crowdfunding sebab ingin ada keterlibatan dari penggemarnya dalam pembuatan album. Jono Terbakar menggunakan dua situs crowdfunding dan satu situs pribadi dalam melangsungkan empat kali crowdfunding.

Jono Terbakar menggunakan situs wujudkan.com pada crowdfunding pertamanya pada bulan Oktober 2015 untuk pendanaan album pertama Jono Terbakar yang berjudul "Dunyakhirat". Jono Terbakar memberikan tiga jenis imbalan untuk donor yaitu: a) CD; b) kaos dan CD; serta c) kaos, CD, dan totebag. Crowdfunding "Dunyakhirat" berlangsung selama tujuh belas hari dan mengumpulkan Rp15.573.767,00 dari 119 donor.

Crowdfunding "Ziarah" adalah crowdfunding kedua dari Jono Terbakar yang dilakukan pada bulan Juli 2017 melalui situs kitabisa.com. Pada crowdfunding "Ziarah", Jono Terbakar hanya menyiapkan imbalan berupa ucapan terima kasih melalui pesan WhatsApp, tidak ada benda fisik yang dikirimkan. Crowdfunding “Ziarah" berlangsung selama empat belas hari dan mengumpulkan Rp800.572,00 dari tiga donor. 
Pada Agustus 2018, Jono Terbakar melakukan crowdfunding ketiga yang ditujukan untuk pendanaan album "Proposal Penelitian". Crowdfunding ketiga dilakukan melalui situs pribadi band Jono Terbakar (jonoterbakar.com). Terdapat lima paket imbalan yang ditawarkan pada crowdfunding "Proposal Penelitian": a) stiker logo Jono Terbakar; b) stiker logo Jono Terbakar dan CD "Proposal Penelitian"; c) stiker logo Jono Terbakar, CD "Proposal Penelitian", dan totebag "Proposal Penelitian"; d) stiker logo Jono Terbakar, CD "Proposal Penelitian", totebag "Proposal Penelitian", dan kaos "Proposal Penelitian"; dan e) stiker logo Jono Terbakar, CD "Proposal Penelitian", totebag "Proposal Penelitian", kaos "Proposal Penelitian", dan topi Universitas Jono Terbakar. Crowdfunding "Proposal Penelitian" berlangsung selama 20 hari pada tanggal 3 - 24 Agustus 2018 dan mengumpulkan Rp5.000.000,00 dari 25 pendonor. Pendonor pada crowdfunding ini memberikan uang dalam jumlah yang berbeda-beda sesuai dengan paket yang dipilih. Paket (a) senilai Rp20.000,00 atau kurang; Paket (b) senilai Rp50.000,00; Paket (c) senilai Rp150.000,00; Paket (d) senilai Rp200.000,00; dan Paket (e) senilai Rp250.000,00.

Crowdfunding Jono Terbakar yang terakhir adalah dalam rangka mengumpulkan dana untuk album "Happy Mental". Crowdfunding "Happy Mental" dilakukan melalui situs kitabisa.com selama 14 hari dan mengumpulkan Rp2.135.000,00. Pada crowdfunding "Happy Mental", Jono Terbakar hanya menyediakan satu paket imbalan berupa pencantuman nama pada credit album.

Crowdfunding merupakan salah satu opsi yang dapat digunakan oleh musisi untuk menggalang dana dari penggemar maupun nonpenggemar. Crowdfunding yang dilakukan Jono Terbakar menarik orang-orang yang dikenal oleh salah satu atau seluruh personel Jono Terbakar dan juga orang yang tidak kenal sama sekali kepada salah satu atau seluruh personel Jono Terbakar. Setiap crowdfunding yang dilakukan Jono Terbakar adalah crowdfunding untuk produksi album. Mengetahui lebih jauh mengenai motivasi dari pendonor yang pernah berpartisipasi dalam crowdfunding album-album Jono Terbakar, mungkin dapat membantu Jono Terbakar dan juga musisi lainnya untuk lebih mudah dan lebih baik dalam menyusun strategi crowdfunding. Penelitian ini dimaksudkan untuk mendalami motivasi donor pada crowdfunding yang pernah diselenggarakan oleh Jono Terbakar.

\section{Crowdfunding}

Menurut Gerber \& Hui (2014), crowdfunding adalah penggalangan daring terhadap sumber daya kepada orang banyak yang kadang melibatkan imbalan. Secara umum, crowdfunding menggunakan platform yang merupakan pihak ketiga yang akan menampung dana sampai penggalangan dana berakhir dan pada umumnya akan memotong komisi sesuai dengan ketentuan platform-nya (Kraus, et 
al., 2016). Crowdfunding terinspirasi dari micro-finance dan crowdsourcing (Mollick, 2014). Dana yang didapatkan oleh kreator akan menjadi banyak berkat banyaknya donor yang berpartisipasi dalam jumlah yang sedikit.

Platform crowdfunding pertama adalah ArtistShare yang berdiri pada tahun 2003 di Amerika. Proyek pertama dari ArtistShare adalah penggalangan dana untuk album jaz Maria Schneiders yang berhasil menggalang dana sebesar \$ 130.000 USD (Freedman \& Nutting, 2014). Keberhasilan ArtistShare membuat semakin banyak bermunculan situs crowdfunding lainnya seperti kickstarter.com.com, indiegogo.com, dan kitabisa.com.

Terdapat tiga pihak yang terkait dalam crowdfunding: kreator, platform, dan donor. Kreator adalah orang atau kelompok yang menggalang dana. Platform adalah proyek penggalangan dana dibuat dan tempat dana dikumpulkan. Donor adalah orang yang memberi dana kepada kreator.

Kraus, et al. (2016) menyebutkan terdapat empat basis crowdfunding yaitu 1) berbasis donasi, 2) berbasis imbalan, 3) berbasis kepemilikan saham, dan 4) berbasis pinjaman. Pada crowdfunding berbasis donasi, donor tidak mengharapkan apapun sebagai imbalan dari dana yang diberikan, sedangkan pada crowdfunding berbasis imbalan, donor mengharapkan adanya imbalan yang setimpal dari dana yang diberikan. Imbalan ditentukan oleh kreator sehingga donor dapat memilih paket imbalan sesuai yang diinginkan. Pada crowdfunding berbasis kepemilikan saham, donor akan mendapatkan saham atas dana yang masuk. Crowdfunding jenis ini banyak digunakan oleh perusahaan rintisan yang sedang mencari modal awal bagi usahanya. Pada crowdfunding berbasis pinjaman yang biasa digunakan oleh perusahaan for-profit, donor mengharapkan pengembalian dana ditambah bagi hasil atau bunga. Crowdfunding album musik cenderung berbasis imbalan di mana donor akan mendapatkan imbalan atas dananya berupa rilisan fisik atau suvenir lain dari musisi tersebut, seperti kaos, topi, dll (Gerber \& Hui, 2014).

Hossain \& Oparaocha (2016) menyebutkan bahwa crowdfunding dapat dibagi dalam dua kategori besar yaitu komersial dan filantropi. Crowdfunding komersial digunakan oleh perusahaan ataupun proyek yang mencari profit dan donor mengharapkan dananya kembali dalam bentuk uang yang jumlahnya lebih banyak dari yang diberikan atau dalam bentuk saham. Kategori yang kedua, crowdfunding filantropi digunakan oleh perusahan, individu, atau proyek yang tidak mengembalikan imbalan dalam bentuk uang atau saham kepada donor. Crowdfunding filantropi adalah kategori yang lebih banyak digunakan oleh seniman, terutama musisi walaupun tidak tertutup kemungkinan musisi untuk membuat crowdfunding dalam kategori komersial. Dana yang diberikan donor akan dikembalikan dalam bentuk uang. Penggalangan dana di Indonesia sudah marak sejak lama namun bentuk penggalangan dana dalam bentuk crowdfunding melalui platform digital baru masuk di Indonesia pada sekitar tahun 2013. 


\section{Motivasi}

Motivasi adalah alasan yang melatarbelakangi perilaku yang ditandai oleh keinginan. Motivasi melibatkan sekumpulan kepercayaan, persepsi, nilai, ketertarikan, dan aksi yang semuanya saling berhubungan dekat (Lai, 2011). Gredler, et al. (2004) mendefinisikan motivasi sebagai sebuah atribut yang membuat seseorang melakukan atau tidak melakukan suatu hal.

Motivasi dapat dibagi menjadi dua yaitu motivasi intrinsik dan motivasi ekstrinsik. Motivasi intrinsik berasal dari dalam diri seperti kenyamanan personal, ketertarikan, dan kenikmatan. Motivasi ekstrinsik berasa dari luar diri yang biasanya membuat perilaku harus dilakukan karena terpaksa (Liu, 2011).

\section{Motivasi Donor}

Mollick (2014) menyebutkan bahwa terdapat empat kategori motivasi donor crowdfunding: a) motivasi sebagai patron, b) motivasi mencari imbalan, c) motivasi memberi pinjaman, dan d) motivasi mendapat saham kepemilikan. Donor yang memiliki motivasi sebagai patron akan memberi dana tanpa berharap dananya kembali dan tidak berharap akan imbalan. Donor dengan motivasi menjadi patron ditemukan pada proyek-proyek sosial seperti pada crowdfunding bantuan untuk korban bencana alam. Gerber \& Hui (2014) menemukan bahwa salah satu jenis motivasi donor adalah motivasi untuk membantu sesama. Dalam membantu sesama, donor tidak mengharapkan imbalan, tidak mengharapkan pengembalian modal beserta bagi hasil/bunga, serta tidak bertujuan untuk bergabung dalam sebuah komunitas.

Kategori kedua dari motivasi donor yang diajukan Mollick (2014) adalah motivasi mencari imbalan. Donor termotivasi untuk mengikuti crowdfunding karena kreator menyebutkan bahwa akan memberi imbalan sesuai dengan dana yang diberikan. Pada situs web crowdfunding kickstarter.com.com dan kolase.com, kreator dapat memberikan beberapa paket imbalan yang tiap paket memiliki perbedaan pada jumlah dana yang harus diberikan oleh donor. Motivasi mencari imbalan terdapat pada donor yang mengikuti crowdfunding kategori filantropi, dengan imbalan sebagai timbal balik nonkomersial yang diberikan oleh kreator pada donor (Hossain \& Oparaocha, 2016).

Kategori ketiga yang diajukan Mollick (2014) adalah motivasi memberi pinjaman. Donor yang memberi pinjaman mengharapkan dana dikembalikan dalam bentuk uang. Motivasi memberi pinjaman banyak ditemukan pada donor yang berpartisipasi pada crowdfunding peer-to-peer lending. Umumnya, kreator proyek adalah perusahaan atau individu yang menggalang dana untuk kebutuhan bisnis sehingga diharapkan menghasilkan profit dalam bentuk uang (Hossain \& Oparaocha, 2016). 
Kategori keempat yang diajukan Mollick (2014) adalah motivasi mendapat saham. Donor memberikan dana untuk mendapatkan sebagian kepemilikan atas perusahaan atau produk yang dihasilkan. Donor menjadi investor dalam kategori motivasi ini. Investor akan mendapatkan kenaikan nilai investasi dari produk yang ia danai.

Menurut Hossain \& Oparaocha (2016), tiga pendekatan terkait motivasi donor tadi membuat adanya perbedaan dalam bentuk crowdfunding. Pada model patron, dana yang diberikan merupakan donasi. Pada model pinjaman, dana yang diberikan adalah utang. Dan pada model imbalan, dana yang diberikan merupakan bentuk lain dari pre-order produk dari kreator.

\section{METODE}

Penelitian ini menggunakan metode kualitatif dengan pendekatan studi kasus dan analisis deskriptif. Variabel yang diteliti adalah 1) motivasi intrinsik yaitu motivasi yang muncul dari dalam diri dengan subvariabel "mendukung gagasan" dan "membantu orang lain" serta 2) motivasi ekstrinsik yaitu motivasi yang datang dari luar diri dengan subvariabel "mendapat imbalan nonfinansial" dan "motivasi sosial karena orang lain mengikuti". Instrumen yang digunakan adalah wawancara secara langsung dan tidak langsung. Dari populasi yang merupakan seluruh orang sejumlah 170 orang yang pernah menjadi pendonor crowdfunding Jono Terbakar, diambil enam orang yang dipilih secara purposive sampling sebagai subjek penelitian. Sampel yang dipilih adalah orang yang mudah untuk diakses dan minimal pernah mengikuti satu kali crowdfunding Jono Terbakar.

Data primer didapatkan melalui wawancara, sedangkan data sekunder didapatkan melalui studi pustaka. Hasil wawancara kemudian dibuat transkripnya dan direduksi datanya menggunakan koding yang sudah disiapkan peneliti untuk membantu memahami pola dan makna dari kalimat-kalimat wawancara. Data yang sudah direduksi kemudian dianalisis dan dikaitkan dengan variabel-variabel yang diteliti. Setelah itu data disajikan dan ditarik kesimpulannya.

\section{PEMBAHASAN}

\section{Jono Terbakar}

Jono Terbakar adalah sebuah proyek kesenian yang berdiri sejak tahun 2013 di Yogyakarta, Indonesia. Jono Terbakar diinisiasi oleh Nihan Lanisy dan kemudian ditambah Muhammad Nur Hidayat. Bermula dari musik, Jono Terbakar lahir ketika Nihan Lanisy sedang berkuliah di Jurusan Manajemen, Universitas Gadjah Mada pada tahun 2012 dan merekam lagu-lagunya menggunakan gawai. Lagu-lagu yang kemudian diunggah di Soundcloud tersebut ternyata disukai oleh 
teman-teman terdekatnya dan membuat Nihan Lanisy mulai mementaskan lagulagu tersebut di panggung. Muhammad Nur Hidayat adalah orang yang selalu hadir di masa awal Nihan Lanisy berkeliling mementaskan Jono Terbakar sampai pada suatu hari di tahun 2013, Muhammad Nur Hidayat resmi bergabung di Jono Terbakar sebagai personel kedua.

Jono Terbakar sering tampil di acara pentas seni sekolah atau kampus di Yogyakarta sejak tahun 2013. Pada tahun 2014, Nihan Lanisy memutuskan untuk membubarkan Jono Terbakar karena alasan keagamaan. Nihan Lanisy menganggap bahwa musik itu haram sehingga ia membubarkan Jono Terbakar. Pada tahun pertengahan 2014 sampai dengan akhir 2015, Jono Terbakar bubar dan tidak ada aktivitas sama sekali. Pada akhir 2015, Nihan Lanisy akhirnya kembali bermain musik setelah berproses dengan gagasan "musik haram". Jono Terbakar kembali dengan sebuah album berjudul "Dunyakhirat" yang dirilis pada November 2015. Album ini merupakan album pertama Jono Terbakar yang didanai oleh masyarakat melalui crowdfunding wujudkan.com. Sebanyak 114 orang menjadi pendonor pada crowdfunding ini sehingga Jono Terbakar dapat mengumpulkan dana sekitar Rp 15.000.000,00.

Tahun 2015-2016, Jono Terbakar masih tidak aktif sebagai entitas seni karena kesibukan masing-masing personel. Pada tahun 2017, Jono Terbakar aktif kembali karena sebuah album berjudul "Ziarah". "Ziarah" adalah sebuah album yang merupakan musik pendukung film "Ziarah", sebuah film independent yang disutradarai B. W. Purbanegara dan berhasil masuk ke bioskop dan ditayangkan selama dua minggu. Jono Terbakar melakukan penafsiran ulang terhadap film "Ziarah" dan melakukan adaptasi media dari film ke musik. Album ini menandakan bahwa Jono Terbakar aktif kembali di kancah dunia permusikan Yogyakarta. Jono Terbakar mulai mengisi lagi panggung-panggung pentas seni sekolah dan kampus di Yogyakarta. Album "Ziarah" juga didanai sebagian melalui crowdfunding. Crowdfunding "Ziarah" tidak mendapatkan promosi yang cukup dari Jono Terbakar, hanya dibuka crowdfunding-nya dan disebarkan tautannya satu kali di awal saja, sehingga crowdfunding ini hanya diikuti oleh tiga orang dan mendapatkan dana sebesar Rp 500.000,00. Pada tahun 2017 juga, Jono Terbakar merilis album "Pesantren Kilat". Album ini didanai sendiri oleh Jono Terbakar. Album yang berisi tiga lagu ini merupakan album yang dirilis pada saat bulan Ramadhan tahun 2017.

Pada tahun 2020, Jono Terbakar telah merilis 20 album (10 full-album dan 10 mini-album). Kedua puluh album tersebut untuk pendanaan produksi album, Jono Terbakar telah melakukan crowdfunding sebanyak lima kali yaitu untuk album "Dunyakhirat" (2015), "Ziarah" (2017), "Proposal Penelitian" (2018), "HappyMental" dan "Karoseri" (2018), serta "Mudah dan Murah" (2019). Setelah album "Mudah dan Murah", Jono Terbakar jarang melakukan crowdfunding karena Jono 
Terbakar telah disponsori oleh studio DS Records Yogyakarta untuk produksi album sehingga tidak membutuhkan biaya lagi untuk rekaman.

\section{Crowdfunding Jono Terbakar}

Sampai dengan tahun 2020, Jono Terbakar telah melakukan lima kali crowdfunding. Pertama kali dimulai pada tahun 2015 untuk penggalangan dana album "Dunyakhirat". Pada tahun 2017, Jono Terbakar melakukan crowdfunding untuk album "Ziarah". Pada tahun 2018, Jono Terbakar melakukan dua kali crowdfunding untuk album "Proposal Penelitian" dan "Happy-Mental" / "Karoseri”. Pada tahun 2019, Jono Terbakar melakukan crowdfunding untuk album "Mudah dan Murah".

Jono Terbakar menggunakan platform wujudkan.com, kitabisa.com, kolase.com, dan jonoterbakar.com untuk melakukan crowdfunding. Terdapat 170 orang yang pernah mengikuti crowdfunding Jono Terbakar.

\section{Hasil Penelitian Terkait Motivasi Pendonor}

\section{A) Mendukung Gagasan}

Crowdfunding yang dilakukan Jono Terbakar adalah sebuah usaha dan gagasan mendapatkan dana dari masyarakat untuk menutupi biaya produksi album. Gagasan tersebut dapat diperluas juga secara teknis pada album, lagu, atau karya dari Jono Terbakar sendiri. Pada penelitian ini, ditemukan bahwa terdapat narasumber yang mengungkapkan bahwa mereka mengikuti crowdfunding untuk mendukung sebuah gagasan. Dukungan terhadap gagasan entitas Jono Terbakar tersebut termuat di dalam album dan lagu-lagu Jono Terbakar.

"Saya lebih ke anu sih, lebih support aja sih bukan karena, o dibalik ini ada sesuatu gitu. Awalnya sih memang support tapi ternyata anu nih opo, ada oleholeh dari Mas Jono-nya. Jadi sesuatu yang luar biasa sih", (wawancara dengan Mardianto Tiro). Mardianto Tiro mengungkapkan bahwa ia melakukan untuk "support" dan ketika mengetahui bahwa terdapat imbalannya itu dianggap sebagai bonus saja. Penulis menginterpretasikan "support" dalam kalimat di atas sebagai sebuah bentuk dukungan pada gagasan Jono Terbakar. Meskipun "support" dapat berarti "membantu orang lain", namun dalam konteks kalimat tersebut, Mardianto Tiro bermaksud mendukung agar album tersebut dapat diproduksi.

Hal tersebut ditambah dengan pernyataan selanjutnya yang jawabannya didapatkan dari pertanyaan lain. "Bakal tetep support, tetep mengikuti itu sih. Kalau namanya support ya engga mengharapkan imbalan", (wawancara dengan Mardianto Tiro). Bagi Mardianto Tiro, antara "support" dengan imbalan berbanding terbalik. Penulis menginterpretasikan bahwa untuk beberapa orang, seperti Mardianto Tiro, menganggap bahwa ketulusan dan keikhlasan dalam mendukung sebuah karya sangat penting. Imbalan diletakkan di tempat terbawah 
sehingga motivasi untuk mendukung gagasan yang muncul dari dalam diri memiliki tempat sebagai prioritas. Hal ini didukung juga dengan pernyataan dari Resya Arva Vradana, "Kalau waktu itu aku malah melihat dari supporting dan dari konten, jadi soalnya kan waktu itu aku liat pas jono terbakar emang baru pertama kali bikin full album ini ya".

Resya Arva mengikuti crowdfunding "Proposal Penelitian". "Proposal Penelitian" merupakan album pertama Jono Terbakar yang direkam dalam format full-band. Secara normal Jono Terbakar merekam albumnya dalam format akustik sederhana dengan hanya menggunakan vokal, gitar, dan marakas. "Proposal Penelitian" merupakan album yang baru bagi beberapa orang. Penulis menginterpretasikan bahwa Resya Arva penasaran dan mendukung gagasan dari album "Proposal Penelitian" supaya bisa terselesaikan dan dirilis. Ia menyebutkan "konten" dan "emang baru pertama kali" sebagai ketertarikannya mengikuti crowdfunding.

"Pertama, karena suka lagu-lagunya Jono Terbakar, terus antusis pingin gek ndang ono meneh. Karya-karya soko Jono Terbakar ki ono meneh ngono terus yo walaupun ga seberapa tapi paling engga ikut urun dan bisa apa ya", (wawancara dengan Khusnudoni). Berbeda dengan Mardianto Tiro dan Resya Arva Vradana, Khusnudoni menyebutkan bahwa ia ingin bahwa album Jono Terbakar ada lagi. Ia ingin ada karya baru dari Jono Terbakar, sehingga ketika Jono Terbakar membuka crowdfunding, ia merasa itu adalah peluang untuknya dapat berkontribusi dan juga untuk membantu kebutuhan produksi Jono Terbakar. Penulis menginterpretasikan bahwa dalam mendukung gagasan, Khusnudoni tertarik dari sisi supaya ada lagi karya yang baru, terlepas dari format musik, tema, dan hal lain.

\section{B) Membantu Orang Lain}

Crowdfunding dapat digunakan untuk membantu orang lain. Seperti yang terjadi pada situs web kitabisa.com, kebanyakan kampanye crowdfunding yang tersedia di kitabisa.com adalah penggalangan dana sosial untuk bencana alam, orang sakit, pembangunan tempat ibadah, dan bantuan-bantuan lainnya. Crowdfunding yang dilakukan Jono Terbakar dilakukan dengan tujuan meminta bantuan orang lain. Cukup berbeda dengan yang ada pada situs web kitabisa.com, crowdfunding Jono Terbakar menawarkan imbalan bagi pendonor yang mengikuti crowdfunding tersebut.

Mendukung gagasan dan membantu orang lain adalah dua motivasi yang muncul dari dalam diri. Secara pribadi, seseorang ingin mendukung gagasan dan membantu orang lain melalui crowdfunding. Membantu orang lain dikategorikan kepada hal yang memasukkan komponen rasa iba dan peduli dalam mengikuti crowdfunding. Melalui wawancara dan interpretasi, penulis menemukan bahwa 
beberapa responden mengikuti crowdfunding dengan motivasi "membantu orang lain".

"Memang kebetulan juga lagi, apa namanya, lagi banyak berkat juga sih. Jadi sambil berbagi kebahagiaan juga sama Mas Jononya", (wawancara dengan Mardiato Tiro). Mardianto Tiro mengungkapkan dengan kalimat "lagi banyak berkat sih, jadi sambil berbagi kebahagiaan sama Mas Jononya”. Penulis menginterpretasikan kalimat tersebut sebagai sebuah tanda bahwa pendonor memiliki rasa iba atau peduli kepada Jono Terbakar dan kemudian mengikuti crowdfunding. Hal ini menarik karena Mardianto Tiro sebelumnya juga mengungkapkan beberapa hal yang dikategorikan oleh penulis dalam motivasi mendukung gagasan. Satu orang dapat memiliki motivasi lebih dari satu dalam mengikuti crowdfunding Jono Terbakar. Selain menyebutkan bahwa ingin "mendukung gagasan" pada poin A) di atas, ia juga ingin membantu orang lain melalui crowdfunding Jono Terbakar.

"Emang udah naitku full ini lho untuk apa ya, membantu untuk support", (wawancara dengan Resya Arva Vradana). "Membantu untuk support" seperti yang diungkapkan oleh Resya Arva adalah sebuah pernyataan yang menunjukkan bahwa seorang pendonor mengikuti crowdfunding untuk membantu orang lain atas landasan iba atau peduli. Resya Arva mengikuti crowdfunding Proposal Penelitian pada waktu itu dengan mengambil paket imbalan senilai Rp 250.000,00. "Kalo saya pribadi memang untuk support produksi jono terbakar, nek pas punya rejeki turah (nek ra turah ya inshaallah tak turah2ke)", (wawancara dengan Agnes Chella). Agnes Chella menyebutkan bahwa ia bukan kolektor dari merchandise Jono Terbakar. Ia mengikuti crowdfunding untuk dapat membantu produksi album Jono Terbakar.

\section{C) Mengharapkan Imbalan Nonfinansial}

Pada penelitian kali ini, penulis menemukan responden yang mengikuti crowdfunding memiliki motivasi yang berbeda dari dua pendonor. Gernata Titi menyebutkan bahwa, "Saya ikut untuk mengkoleksi merchandisenya". Secara langsung ia mengakui bahwa mengikuti crowdfunding untuk mendapatkan imbalan nonfinansial berupa CD dan kaos pada crowdfunding album "Mudah dan Murah".

Lain halnya dengan yang diungkapkan oleh Kristiawan Bayu, "Nek pas album Dunyakhirat 50:50, Proposal 80:20”. Bayu Kristiawan telah mengikuti crowdfunding sebanyak dua kali. Pada crowdfunding album "Dunyakhirat" tahun 2015, 50\% motivasinya adalah mengoleksi CD dan kaos eksklusif dari crowdfunding tersebut. Pada tahun 2018, Bayu Kristiawan mengikuti crowdfunding album "Proposal Penelitian". Bayu Kristiawan menyebutkan bahwa pada crowdfunding "Proposal Penelitian", harapannya turun jadi $20 \%$ terhadap imbalan 
berupa kaos, CD, dan totebag karena $80 \%$ motivasinya untuk mendukung albumnya selesai diproduksi dan dirilis.

\section{D) Motivasi Sosial}

Dalam pengolahan data setelah wawancara, penulis tidak menemukan responden yang mengikuti crowdfunding karena "motivasi sosial" (mengikuti crowdfunding karena orang lain melakukan hal tersebut). Sama sekali tidak tersebut dari satupun narasumber tentang keikutsertaannya pada crowdfunding Jono Terbakar yang terpengaruhi dari orang lain atau desakan orang lain.

\section{Pembahasan}

Pada penelitian ini, didapati bahwa motivasi seorang pendonor dapat lebih dari satu motivasi. Sebagai contoh, Bayu Kristiawan yang menyebutkan prosentase 50:50 dan 80:20 pada perbandingan antara mendukung produksi dan keinginan akan merchandise yang ditawarkan crowdfunding tersebut. Di sisi lain, dari seluruh responden didapati hanya satu responden saja yaitu Gernata Titi yang mengikuti crowdfunding untuk mendapatkan imbalannya, kala itu berupa $\mathrm{CD}$ dan kaos eksklusif.

Penelitian ini menemukan juga bahwa pendonor lebih terpengaruhi motivasi intrinsik daripada motivasi ekstrinsik. Melalui data yang didapatkan, hanya satu orang responden yang motivasinya murni untuk mendapatkan imbalannya (collecting merchandise). Motivasi intrinsik, yang keluar dari dalam diri, lebih dominan didapati pada penelitian ini. "Mendukung Gagasan" menjadi motivasi dominan dari mayoritas responden kemudian disusul oleh "Membantu Orang Lain".

Meskipun begitu, beberapa responden memiliki motivasi yang terkait dengan motivasi intrinsik dan ekstrinsik. Imbalan yang berupa pencantuman nama di kredit album dan atau merchandise, juga disebutkan oleh beberapa responden, walaupun tidak dominan. Sebagian besar responden termotivasi untuk "mendukung gagasan" dan atau "membantu orang lain" dan kemudian menjadikan merchandise sebagai bonus, dan tidak menjadi motivasi utama. Beberapa responden dapat menjawab pertanyaan ketika ditanya mengenai motivasinya antara "support dan mendapat merchandise" melalui prosentase, sebagai contoh, Mardianto Tiro memberikan jawaban, "Support, imbalannya persennya kecil sekali".

Kitabisa.com merupakan salah satu platform yang banyak disebut oleh para responden. Beberapa crowdfunder menyatakan bahwa sudah pernah mengikuti crowdfunding berbasis donasi seperti kitabisa.com. Crowdfunding berbasis donasi tidak memberikan imbalan pada pendonor. Crowdfunding yang dilakukan Jono Terbakar cukup berbeda dengan crowdfunding untuk donasi bencana alam, membangun tempat ibadah, orang sakit, atau crowdfunding sosial lainnya. Adanya 
imbalan yang diberikan, cukup menarik untuk pendonor walaupun tidak menjadi motivasi utama secara signifikan. Produksi album musik yang berisi lagu-lagu, yang merupakan tujuan utama crowdfunding Jono Terbakar, adalah sebuah manifestasi dari sesuatu yang intangible (tidak berwujud). Pendonor hanya membaca proposal crowdfunding dan dapat melihat portofolio dari karya-karya Jono Terbakar. Adanya imbalan membuat pendonor mendapatkan sesuatu yang tangible (berwujud).

\section{KESIMPULAN}

Menurut penelitian ini, seseorang mengikuti crowdfunding dengan motivasi yang lebih dari satu jenis. Motivasi intrinsilk menjadi motivasi yang dominan muncul. "Mendukung gagasan" dan "membantu orang lain" menjadi dua motivasi utama dari pendonor crowdfunding Jono Terbakar. "Mendukung gagasan" memiliki kecenderungan yang lebih tinggi dibandingkan dengan "membantu orang lain".

Imbalan nonfinansial merupakan keunikan dari crowdfunding Jono Terbakar. Imbalan, walau tidak menjadi motivator utama, tetap muncul sebagai motivasi dari pendonor. Digambarkan oleh salah satu narasumber penelitian bahwa antara "mendukung gagasan/membantu orang lain" jika dibandingkan dengan “mengharap imbalan", dapat dibantu dengan prosentase (50:50 atau 80:20). Hal ini sekaligus menjadi saran untuk musisi yang ingin membuat kampanye crowdfunding untuk memperhatikan dengan baik imbalan dan paket imbalan yang ditawarkan.

\section{KEPUSTAKAAN}

Assenova, Valentina, Jason Best, Mike Cagney, Douglas Ellenoff, Kate Karas, Jay Moon, Sherwood Neiss, Ron Suber, and O. S. (2016). The Present and Future of Crowdfunding. California Management Review, 58(2), 125-135.

Bannerman, S. (2020). Crowdfunding Music and the Democratization of Economic and Social Capital. Canadian Journal of Communication, 45.

Bœuf, Benjamin, Jessica Darveau, and R. L. (2014). Financing Creativity: Crowdfunding as a New Approach for Theatre Projects. International Journal of Arts Management, 16(3), 33-48.

Chang, J.-W. (2020). The Economics of Crowdfunding. American Economic Journal: Microeconomics, 12, 257-280.

Cordova, Alessandro, Johanna Dolci, and G. G. (2015). The Determinants of Crowdfunding Success : Evidence from Technology Projects. Procedia Social and Behavioral Sciences, 181, 115-124.

D’Amato, Francesco \& Cassella, M. (2020). Cultural production and platform mediation: A case in music crowdfunding. New Media \& Society. SAGE Journals. 
Forbes, H. and D. S. (2017). Guidelines for Successful Crowdfunding. Procedia CIRP, 60, 398-403.

Freedman, B. D. M. and M. R. N. (2014). A Brief History of Crowdfunding. Freedman Chicago, 1(1), 10.

Galuszka, Patryk \& Brzozowska, B. (2016). Crowdfunding and the democratization of the music market. SAGE Journals-Media, Culture \& Society, 39(6). https://doi.org/https://doi.org/10.1177\%2F0163443716674364

Hidajat, Taofik, Ina Primiana, Sulaeman Rahman Nidar, and E. F. (2016). . (2016). "Crowd Funding: Financial Service for Unserved Crowds in Indonesia." 109-15. International Conference of Integrated Microfinance Management (IMM-16), 109-115. Atlantis Press.

Hossain, M. and G. O. O. (2016). Crowdfunding: Motives, Definitions, Typology and Ethical Challenges. Entrepreneurship Research Journal, 7(2). https://doi.org/https://doi.org/10.1515/erj-2015-0045

Keyhani, Mohammad \& Neyshabouri, Safaneh \& Amereii, A. (2020). Crowdfunding Canadian Theatre. Artivate: A Journal of Entrepreneurship in the Arts, 9(1).

Kraus, Sascha, Chris Richter, Alexander Brem, Cheng-Feng Cheng, and M.-L. C. (2016). Strategies for Reward-Based Crowdfunding Campaigns. Journal of Innovation \& Knowledge, 1(1), 13-23.

Lin, Yan \& Boh, W. (2019). How Different Are Crowdfunders? Examining Archetypes of Crowdfunders. JASIST-Journal of the Association for Information Science and Technology, 71(11), 1357-1370.

Mollick, E. (2014). The Dynamics of Crowdfunding: An Exploratory Study. Journal of Business Venturing, 29(1), 1-16.

Younkin, P. and K. K. (2016). What Problems Does Crowdfunding Solve? California Management Review, 58(2), 20-43.

Zhang, H. and W. C. (2019). Backer Motivation in Crowdfunding New Product Ideas: Is It about You or Is It about Me? Journal of Product Innovation Management, 36(2), 241-262.

Zheng, Haichao, Bo Xu, Tao Wang, and Y. X. (2017). An Empirical Study of Sponsor Satisfaction in Reward-Based Crowdfunding. Journal of Electronic Commerce Research, 18(3), 269-285.

\section{Webtografi}

Inc.com. (2018). Top 10 Crowdfunding Platform of 2018. Retrieved April 9, 2019, from Inc.com website: https://www.inc.com/larry-kim/op-10crowdfunding-platforms-of-2018.html

Kompas.com. (2018). Berapa Jumlah Pengguna Internet Indonesia? Retrieved April 9, 2019, from kompas.com website: https://tekno.kompas.com/read/2018/02/22/16453177/berapa-jumlahpengguna-internet-indonesia

Wikipedia. (2019). Myspace. Retrieved April 9, 2019, from wikipedia.org 


\section{Informan}

Kristiawan, Bayu. 28 tahun. (2020). Pendonor pada crowdfunding album "Dunyakhirat" dan "Proposal Penelitian" tinggal di Sewon, Bantul.

Vradana, Resya Arva. 22 tahun. (2020). Pendonor pada crowdfunding album "Proposal Penelitian" tinggal di Seturan, Yogyakarta.

Khusnudoni. 19 tahun. (2020). Pendonor pada crowdfunding album "Proposal Penelitian" tinggal di Godean, Sleman.

Titi, Gernata. 39 tahun. (2020). Pendonor pada crowdfunding album "Mudah \& Murah" tinggal di Bangunjiwo, Bantul.

Purwani, Agnes Chella. 27 tahun. (2020). Pendonor pada crowdfunding album "Happy Mental" dan "Proposal Penelitian" tinggal di Salatiga, Jawa Tengah.

Tiro, Mardianto. 25 tahun. (2020). Pendonor pada crowdfunding album "Happy Mental" tinggal di Banguntapan, Bantul.

Hidayat, Muhammad Nur. 29 tahun. (2020). Salah satu kreator crowdfunding Jono Terbakar tinggal di Jalan Veteran, Surakarta.

Azhari, Muhammad Asyam. 25 tahun. (2020). Salah satu tim Jono Terbakar tinggal di Karang Malang, Sleman. 